\title{
KELAS HAJI KELAS SOSIAL Sejarah Haji dari Zaman Kolonial Hingga Kini Ditinjau dari Kajian Kritis Kapitalisme
}

\author{
Asyhadi Mufsi Sadzali \\ Fakultas Ilmu Budaya Universitas Jambi \\ Jl. Lintas Jambi - Muara Bulian Km. 15, Kota Jambi \\ asyhadi@gmail.com
}

\begin{abstract}
Social Classes of Haji Class: History of Hajj from the Colonial Age Till Up Judging from Critical Studies of Capitalism. The current phenomenon of Hajj, which is full of fraud and queuing for up to seven years, is a new form of false awareness created by capitalists. Cases of fraud related to Umroh repeatedly appear to have no deterrent effects and learning for the community. A very interesting phenomenon apparently does not only occur as 'social media' as it is today, but also in the colonial period. Of course this repetitive pattern offers the signs to explore more deeply to the roots of the past, the colonial period. Therefore this study tries to see the other side behind the Hajj procession by using critical studies of capitalism and historical approaches. The historical approach used is to compare the Hajj procession in the colonial period with the present and the social phenomena that occur in it. The final round of the capitalist trail hunt in the Hajj class is in the form of a common thread that we can draw the conclusion that false consciousness and the formation of social classes created by the colonial government as a single capitalist, until now still continues with new fashion today.
\end{abstract}

Keywords: Social Class, Hajj, Colonial, Capitalist.

Abstrak: Kelas Haji Kelas Sosial: Sejarah Haji dari Zaman Kolonial Hingga Kini Ditinjau dari Kajian Kritis Kapitalisme. Fenomena haji dimasa kini yang sarat penipuan dan antri hingga tujuh tahun adalah satu bentuk kesadaran palsu mode baru yang diciptkan para kapitalis. Kasus penipuan terkait umroh yang berulang-ulang kali nampaknya tidak menimbulkan efek jera dan pembelajaran bagi masyarakat. Fenomena yang sangat menarik rupanya tidak hanya terjadi diera 'medsos' seperti saat ini, namun juga terjadi pada masa kolonial. Tentu pola berulang ini menawarkan tanda tanya untuk ditelaah lebih dalam sampai ke akar masa lalu, yakni masa kolonial. Oleh karena itu kajian ini mencoba melihat sisi lain dibalik prosesi ibadah haji dengan mengunakan kajian kritis kapitalisme dan pendekatan historis. Pendekatan historis yang digunakan yakni dengan membandingkan prosesi haji di masa kolonial dengan masa sekarang berikut fenomena sosial yang terajadi dalamnya. Babak akhir dari perburuan jejak kapitalis dalam kelas haji yakni berupa benang merah yang dapat kita tarik kesimpulannya bahwa kesadaran palsu dan pembentukan kelas sosial yang diciptakan pemerintah kolonial selaku kapitalis tunggal, hingga saat ini masih terus berlanjut dengan mode baru zaman now.

Kata Kunci: Kelas Sosial, Haji, Kolonial, Kapitalis.

Pendahuluan

Ketika bangsa Eropa muncul pertama kali di perairan negeri-negeri di bawah angin (Asia Tenggara), kawasan ini sudah berkembang sebagai jalur lalu lintas perdagangan internasional yang ramai. Eksotisme timur dengan kekayaan alamnya membuat para penjelajah mencari jalan menuju negeri di bawah angin. Bangsa-bangsa kuno telah lama memainkan layarnya melintasi samudera untuk mencari kekayaan, kekuasaan dan kepuasan. Catatan sejarah banyak menjelaskan tentang petualangan bangsa India berlayar ke China untuk mencari porselin dan kain sutera, dan sebaliknya bangsa China berlayar ke India untuk mencari permadani dan hiasan-hiasan dari gading dan kulit macan. Diantara dua benua yang berbeda ini terdapat satu 
gugusan kepulaluan yang terkenal dengan istilah Nusantara yang jugaterkenal dengan masyarakat maritimnya. Belum ada catatan pasti sejak kapan bangsa maritim ini mulai menjelajahi samudera, namun banyak bukti-bukti cukup kuat untuk menegaskan bahwa pelaut-pelaut Nusantara jauh sebelum abad masehi telah sampai hingga Afrika, Australia bahkan Eropa. Mereka dengankapal bercadiknya membawa serta hasil alam dan hutan seperti kemenyan, kapur barus dan rempah-rempah. Pada akhirnya hal ini lah yang membawa banyak bangsa berlayar menuju gugusan kepulauan Nusantara sehingga menjadi salah satu tujuan terpenting pelayaran internasional.Sebuah catatan kuno dari zaman Firaun menjelaskan bahwa, "konsumen lada yang pertama kali terdokumentasi, rempah bukan digunakan untuk menyedapkan makanantapi dimasukkan kedalam rongga hidung Ramses II, Firaun teragung yang wafat pada 12 Juli 1224 SM."1 Rempah-rempah membawa pengaruh besar terhadap perkembangan budaya dan sistim kepercayaan di seantero gugusan kepulauan Nusantara. Pengaruh berbagai budaya asing masuk silih berganti dan saling mempengaruhi, mulai dari Hindu yang dibawa bangsa India sampai pengaruh Islam yang kemudian diperkenalkan bangsa Arab.

Hubungan dagang antara bangsa Arab dengan kepulauan Nusantara sudah berlangsung sejak lama. Diperkirakan hubungan ini telah terjalin jauh sebelum adanya agama Islam itu sendiri. Bangsa Arab memang terkenal dengan bangsa pedagang.Mereka melintasi lautan antar samudera dengan menggunakan kapal khas bangsa Arab yang dikenal dengan sebutan "Dhow", kapal tanpa cadik bertiang satu dengan layar besar. Ketertarikan bangsa Arab terhadap rempah-rampah membawa mereka melintasi Laut Merah, lalu ke Mediterania hingga akhirnya sampai ke selat Malaka. Dalam Al-quran banyak disebutkan tentang kamperdan kapur, yang oleh para ahli mengidentifikasikannya dengan kapur barus. Dalam catatan sejarah yang dikumpulkan berdasarkan laporanlaporan para penjelajah dan sumber literatur lainnya, disebutkan bahwa bangsa Arab banyak menggunakan rempah-rempah sebagai bahan obatobatan, "para ilmuwan arab menambahkan resep-resep dan penggunaan rempah-rempah diantaranya, seperti pala yang belum dikenal masyarakat Eropa sekalipun itu di masa Galen (zaman pertengahan)."2 Tidak bisa dipungkuri, dengan adanya kontak dagang antara dua kebudayaan yang berbeda ternyata berdampak pada pertukaran keyakinan, yakni masuknya agama Islam ke Nusantara. Terdapat dua teori umum tentang masuknya Islam di Nusantara, "teori pertama merujuk pada abad ke-7 M (zaman Rasulullah) yang di dasarkan pada adanya kontak perdagangan dan hubungan diplomatik tiga kerajaan: Dinasti T'ang (618 - $907 \mathrm{M})$, Ta-cheh, dan kerajaan Sriwijaya. Teori kedua: pada abad ke-13 didasarkan pada ditemukannya tulisan pada batu nisan Sultan Malik Al-Shaleh yang menyatakan sebagai sultan Aceh yang berkuasa di Kerajaan Aceh, Samudera Pasai."3 Sejarah panjang hubungan dagang kepulauan Nusantara dengan bangsa Arab cukup sebagai salah satu jawaban atas status 
negera Indonesia dimasa kini sebagai Negara berpenduduk muslim terbesar di Dunia. Mayoritas yang kemudian menimbulkan atmosfer fanatik yang kuat dalam kehidupan sosial dan keseharian masyarakatnya. Tidak mengherankan bila kemudian doktrin agama dijadikan salah satu doktrin paling ampuh dalam melawan penjajah Belanda yang meraka sebut dengan istilah "kafir".

Mayoritas muslim yang begitu dominan akhirnya melahirkan sebuah tatanan kelas sosial didalam masyarakat muslim itu sendiri, dimana ada Kyai, Haji, Santri dan masyarakat biasa (Abangan, Santri, Priyai Dalam Masyarakat Jawa). Lingkungan yang sengaja dibentuk oleh segelintir orang dengan menciptakan kelas baru diantara kelas-kelas sosial yang telah ada (bangsawan pribumi, kalangan Eropa, kesatria dll) demi kepentingan politik dan ekonomi. Fenomena ini mulai hadir sejak munculnya kerajaan-kerajaan Islam di Nusantara.Sebut saja misalnya, kesultanan Banten dan Mataram Islam. Hal ini jelas terlihat dalam catatan sejarah, "setelah adanya perkembangan hubungan diplomatik antara kerajaan-kerajaan di Nusantara dengan pemerintah Turki Usmani sebagai pusat pemerintahan Islam, lahir keinginan para raja di Nusantara untuk memperoleh legitimasi gelar Sultan sebagai penguasa sah di wilayah kekuasaannya masing-masing. Diantara raja yang pernah mengirimkan utusan ke Makah ialah Raja Banten, Sultan Ageng Titayasa (1638) dan Raja Mataram Islam, Sultan Agung (1641)."4

Agama merupakan pedoman hidup yang mengatur segala kemaslahatan umat manusia, dan juga sebagai alat komunikasi dengan penciptanya.Dalam ajaran agama Islam terdapat rukun Islam dan rukun imam, dimana kedua rukun ini merupakan dua pedoman penting dalam ajaran Islam yang hakekatnya menuntun pada keimanan dan ketaatan dalam menjalankan ajaran agama. Ibadah haji merupakan rukun Islam kelima yang wajib dilaksanakan umat Islam dengan ketentuan mampu secara fisik, mental dan finansial.Mampu ini mengandung makna yang dalam, yang salah satunya adalah bahwa calon jamaah haji harus mampu menyediakan nafkah materi terhadap keluarga yang ditinggalkan selama prosesi ibadah haji di tanah suci berlangsung. Dengan kata lain, ibadah haji merupakan sebuah prosesi ritual yang benar-benar suci dan tergolong berat. Calon jamaah haji benar-benar harus siap secara fisik, iman, mental dan finansial dalam pelaksanaan ibadah haji.Perbedaan suhu udara yang ekstrem antara Indonesia dan Arab juga menuntut jamaah haji harus siap dengan kondisi fisik yang kuat. Banyak diantara jamaah haji yang setiba di tanah suci terkena wabah penyakit dan bahkan meninggal dunia. Dalam hal ini lah kekuatan mental dan fisik benar-benar di uji dan keimanan yang kuat akanbenarbenar ditempa. Tidak mengherankan dengan beratnya halangan dan rintangan dalam prosesi ibadah haji, maka dalam benak sebagian orang terdapat kebanggan personaldan merasa lebih dalam soal keimanan dibandingkan masyarakat muslim yang belum naik haji. Apalagi bila kita tinjau ke masa lalu (kolonial), dimana prosesi haji begitu sulit dan memakan waktu yang lama (6 bulan) sehingga hal tersebut kemudian memperkuat pengakuan sosial masyarakat terhadap seorang haji. 
Prosesi ibadah haji yang begitu panjang dan melibatkan hubungan antar negara dan budaya ternyata tidak luput dari pengaruh serigala-serigala buas kapitalis. Para kapitalis cukup lihai melihat ini sebagai sumber penghasilan besar yang dapat dihisap dan dimainkan. Terlebih bila dilihat dalam segi jumlah, dimana masyarakat Nusantara mayoritas memeluk agama Islam, dan apabila ini di monopoli akan sangat menguntungkan. Pengaruh kapitalisme dalam prosesi ibadah haji ini ternayata telah ada sejak kolonialisme bertahta di Nusantara. Banyak sendi-sendi dalam prosesi haji yang dimainkan para kapitalis, sebut saja misalnya agen perjalan layanan haji, maskapai transportasi, surat pas atau passport dan lain sebagainya. Fenomena haji dan problematikanya tidak hanya sampai pada persoalan itu, ternayata muncul hal baru yakni adanya faktor psikologis yang memicu niatan tulus beralih demi sebuah kelas sosial dan pengakuan di dalam masyarakat.Pada akhirnya muncul sebuah tradisi dalam masyarakat Indonesia yang beranggapan bahwa gelar haji adalah gelar suci dan juga gelar sosial yang sepatutnya ditinggikan derajatnya untuk menghormati kesucian dan prosesi ritualnya. Lambat laun tanpa disadari hal ini berubah jadi sebuah kesadaran palsu yang terbentuk dalam masyarakatdan juga dengan sengaja pembentukannya dibantu oleh pemerintah kolonial demi kepentingan politik yang kemudian membudaya hingga sekarang. Oleh karena hal tersebut, maka dalam tulisan ini saya akan mencoba mengupas sisi-sisi kapitalisme dan kesadaran palsu yang sengaja dibentuk untuk menciptakan kelas sosial baru dalam masyarakat Nusantara yakni kelas haji. Kajian ini mencoba melihat sisi lain dibalik prosesi ibadah haji dengan mengunakan kajian kritis kapitalisme dan pendekatan historis. Adapun pendekatan historis yang saya pakai adalah dengan membandingkan prosesi haji di masa kolonial dengan masa sekarang berikut fenomena sosial yang terajadi dalamnya.

\section{A. Pembahasan}

\section{a. Haji Di Masa Kolonial}

Kolonialisme adalah akar dari kapitalisme, dimana didalamnya terdapat dominasi dan monopoli mutlak atas segala hal yang dikehendaki oleh pihakpihak pemodal yang dalam kasus ini tergabung dalam bentuk sebuah organisasi usaha dagang bernama VOC (vereenigde Oostindische Compagnie).VOC atau perserikatan dagang Hindia-Timur adalah suatu bentuk monopoli dagang Belanda yang didirikan 20 Maret 1602 dengan wilayah kerja meliputi wilayah Asia. Di Indonesia sendiri VOC lebih dikenal dengan sebutan 'kompeni'yang berasal dari kata compagnieatau perusahaan. VOC terbentuk sebagai reaksi terhadappersaingan dagang dan perebutan komoditi rempah-rempah di wilayah Nusantara dengan Spayol, Portugis dan Inggris.Terbukanya pintu dunia melalui perdagangan akibat perkembangan sistem navigasi pelayaran ternyata menjadi awal dari lahirnya sebuah penjajahan di kepulauan Nusantara. Setuju atau tidak, yang diuntungkan hanyalah penguasa pribumi, yakni para Tuan, Tengku dan Raden. Keterdesakan politik dan keserakahan akan harta dan takut akan kehilangan 
kekuasaan memaksa para Raja mengorbankan rakyatnya untuk dihisap tuan-tuan VOC yang datang dari negeri kecil jauh di sudut Eropa. Sangat ironis sekali apabila kita membayangkan wajahwajah para petani yang lugu dan tidak mengerti apa-apa selain pada kesadaran palsu yang telah lama sengaja diciptakan penguasanya yakni mengabdi pada Rajasebagai hamba. Perjanjian politik kemudian dimainkanantara kedua belah pihak demi posisi aman dengan syarat dan catatan-catatan yang telah disepakati bersama, termasuk monopoli dagang dan pembentukan benteng pertahanan beserta pasukannya.

Pada masa VOC memulai usaha dagangnya di kepulauan Nusantara (1602 M), agama Islam telah tumbuh subur dalam masyarakat baik di wilayah pesisir maupun di pedalaman. Hal ini disebabkan telah adanya hubungan dan interaksi yang kuat dan intens pada abad sebelumnya dengan wilayah Arab, "sumber-sumber Portugis mengatakan, pengiriman lada dan rempah-rempah yang lain dari Aceh ke Laut Merah memainkan peranan penting pada masa pemerintahan Ala'addin Ri'yat Syah al-Kahar. Perdagangan ini mencapai puncaknya pada $1560 \mathrm{M}$. Dilaporkan tentang kedatangan 1.800 kuintal (90 ton) lada dan 3.000 kuintal rempah-rempah yang lain di Jeddah pada tahun $1564 \mathrm{M}$, yang dibawa oleh 32 kapal Islam, sebuah laporan Portugis mengatakan lebih lanjut bahwa orangorang Aceh adalah orang yang paling sering melakukan perdagangan dan pelayaran ke Laut Merah." (Reid, 2011. Hlm. 95). Sumber tersebut cukup menjelaskan situasi dan kondisi keagaman masyarakat Nusantara khususnya Aceh dimasa itu. Apabila kita beranjak jauh ke wilayah Timur kepulauan Nusantara, maka akan kita dapati kesultanan Islam yang telah ada sejak abad ke 15, yakni Goa dan Tallo.

Campur tangan pihak kolonial dalam hal urusan ibadah haji, bermula dengan alasan ketakutan dan kecurigaan terhadap para haji yang baru pulang dari tanah suci. Terdapat kecurigaan bahwa masyarakat Nusantara yang menunaikan ibadah haji di Makah akan membawa pemikiran baru dalam pergerakan Islam untuk menentang kolonialisme. Kecurigaan ini kemudian dijadikan sebagai alat untuk merumah kacakan prosesi ibadah haji untuk memudahkan dalam mengontrol pergerakannya.Namun disisi lainternyatapihak kolonial juga melihat adanya keuntungan ekonomi yang sangat besar apabila melakukan monopoli utuh terhadap prosesi ibadah haji. Ibarat kata pepatah, sekali dayung dua pulau terlampaui. Dengan politik yang sama, dua keuntungan dapat diperoleh.

Tidak bisa dipungkiri bahwa prosesi ibadah haji merupkan ritual tahunan dengan kapasitas jamaah yang jumlahnya luar biasa. Tapi untuk menutupi modus kapitalis dan juga upaya pengontrolan politik tersebut, maka pemerintah kolonial menciptakan sebuah kesadaran palsu yakni dengan menciptakan kecurigaan bahwa Islam itu berbahaya dan memanfaatkan isu internasional pada masa itu tentang gerakan pan islamisme (solidaritas seluruh umat Islam) yang dikumandangkan kerajaan Turki Usmani. Apabila kita cermati, hal tersebut tidak jauh berbeda dengan apa yang terjadi pada saat ini, dimana Islam di cap sebagai 
teroris, radikal, oleh Amerika, dan kemudiaan memanfaatkan isu demokrasi dan anti pemimpin diktator di Negaranegara Timur Tengah. Tentu hal ini patut kita curiga dan mempertanyakan, kenapa dan ada apa?

Mengawali usaha monopoli ibadah haji tersebut, maka pemerintah kolonial mengeluarkan sebuah putusan terkait prosesi ibadah haji untuk pertama kalinya, "pihak kolonial kemudian berupaya menekan jamaah haji dengan mengeluarkan Resolusi (putusan) 1825. Peraturan ini diharapkan tidak hanya memberatkan jamaah dalam hal biaya tetapi sekaligus dapat memonitor aktivitas mereka dalam melaksanakan ritual ibadah haji dan kegiatan lainnya selama bermukim disana". ${ }^{5}$ Rosolusi 1825 berkenaan dengan $\mathrm{ONH}$ (ongkos naik haji) yang ditentukan oleh pihak kolonial sebanyak f.110, tidak termasuk uang pembuatan paspor (surat jalan dari penguasa setempat), biaya hidup, ongkos pulang dan dikenakan wajib lapor kepada pemerintah setempat sepulangnya ke tanah air. Pemerintah kolonial faham betul dengan kekuatan doktrin agama dan juga fanatisme umat Islam di Nusantara, sehingga meraka sangat yakin walaupun telah dikeluarkan Resolusi1825, intensitas dan jumlah jamaah haji tetap akan melimpah dan terus bertambah.

Dibalik itu para agen-agen kapitalis memainkan peranannya dilapangan dengan menciptakan kesadaran palsu dalam pola pikir masyarakat Islam, bahwa haji adalah gelar suci yang terhormat yang harus disanjung dan ditempatkan dalam tatanan sosial teratas masyarak Islam. Antara kapitalisme dan penciptaan kesadaran palsu yang dimainkan kapitalis beserta agen-agennya secara bersamaan dalam satu meja judi, ternyata menghasilkan keuntungan yang sangat luar biasa, "biaya yang diperlukan untuk menunaikan ibadah haji sekali jalan bervariatif, namun secara umum diketahui bahwa harga tiket standar f.110 ditambah dengan jasa perusahaan dan syekh f.17,5 maka jumlah ongkos transportasi yang dikeuarkan sebesar f.127,5. (ongkos pergi). Namun secara keseluruhan pemerintah Belanda meminta setiap calon jamaah harus menyetor f.500" (Majid, 2008.Hlm. 55).Bisa dibayangkan keuntungan yang diperoleh pemerintah kolonial dimusim haji bila total penumpang dari delapan pelabuhan dalam satu keberangkatan mencapai ribuan orang, "pada waktu musim haji 1927-1928 jamaah yang berangkat menunaikan ibadah haji ke Makah berjumlah 33.965 orang yang terdiri atas; 10.970 orang berangkat dengan perusahaan Rotterdamsche Lloyd, menggunakan perusahaan Nederlandsche Lloyd 9.467 orang, dan perusahaan Ocean 10.634 orang. Selama musim haji itu, tiap perusahaan mengoperasikan kapalnya antara 7 samapi 9 kali."6 Walaupun dengan biaya yang begitu mahal, jamaah haji tidak mendapatkan fasilitas yang memadai dalam prosesi ibadah haji, "persaingan maskapai kapal Belanda (KPM) yang disebut dngan istilah kongsi tigadengan maskapai kapal Inggris, Arab, dan Singapura, namun pada umumnya maskapai tidak ada yang mengutamakan kesehatan dan kesejahteraan penumpang atau jamaah haji."7

Peningkatan calon jamaah haji terus bertambah dari tahun ke tahun, dan masyarakat Nusantara seperti berlomba- 
lomba untuk berangkat ke tanah suci dengan berbagai macam motif dan alasan masing-masing. Melihat perkembangan ini, pemerintah kolonial merasa kurang mampu untuk mengelolanya sendiri, dan maskapai pemerintah kolonial (KPM) yang dikenal dengan sitilah "kongsi tiga" yakni, Rotterdamsche Lloyd, Nederlandsche Lloyd dan Ocean Llloyd tidak mampu melayani pemberangkatan dan kepulangan jamaah haji yang begitu banyak, apalagi mengingat kapasitas kapalnya yang terbatas. Dari laporan arsip Belanda kita bisa melihat terjadinya peningktan jumlah jamaah tersebut, “jumlah jamaah meningkat lagi pada tahun 1890 menjadi 10.040 orang, dan peminatnya selama kurun waktu 1891 1893 mengalami fluktuatif 18.017, 11.508, 13.856 orang." 8

Setelah proes panjang dalam lelang kerjasama, maka hadirllah Firma Herklots yang berkedudukan di Batavia dan Firma Al-segaff yang berkedudukan di Singapura.Kedua Firma ini mempunyai karakter yang berbeda, baik secara kebangsaan pemiliknya, tempat kedudukan kantornya, maupun caranya dalam pemberangatan jamaah hajinya.Firma Herklot dimiliki seorang Indo-Belanda bernama J.G.M Herklots.Sedangkan Firma Al-Segaff dipimpin oleh Sayid Mohamad Bin Achmad al-Segaff, seorang Indo-Arab. Keduanya memeliki cara yang berbeda dalam usahanya, namun terdapat satu kesamaan yakni sama-sama hanya memikirkan keuntungan tanpa memperdulikan kesehatan dan kesejahteraan penumpang atau jamaah haji. Hal ini jelas terlihat dari laporanlaporan jamaah kepada residen ataupun kewedanaan tempat masing-masing jamaah, namun pemerintah kolonial tidak bertindak untuk mengatasinya dengan alasan hukum dan agama, "bahkan Gubernur Jenderal di Makah, Ahmad Ratib Pasha, mengatakan bahwa tindakan Herklots ini tidak dapat diprotes kerena sejauh ini ia bekerrja untuk kepentingan agama."9 Herklots dalam usahanya menjalankan penipuan secara terangterangan kepada para jamaah.Herklots melakukan monopoli besar-besaran atas keberangkatan jamaah haji di Nusantara. Herklots bergerak sebagai agen tunggal satu-satunya, dan dalam penentuan harga dimonopoli sesuka hati dengan pungutanpungutan liar yang sangat memberatkan jamaah haji. Bahkan banyak diantara mereka sampai kehabisan uang dan akhirnya tidak bisa pulang ke tanah air.Herklots memainkan sistim kapitalis yang kejam dan terang-terangan, "bahkan Herklots memberi wewenang kepada para syekh (pegawai Herklots di lapangan) untuk memungut biaya sewa unta sebesar 15 ringgit (Belanda) sebagai kenderaan meninggalkan Makah, dan setiap penumpang yang akan turun kapal harus membayar 37 ringgit, dan bagi siapa yang tidak mau membayar akan ditangkap oleh laskar, dan sesampai di Jeddah tidak boleh naik kapal lain."10

Penumpang diterlantarkan begitu saja setiba di pelabuhan, baik saat hendak berangkat ke Makah ataupun saat pulang dari Jeddah, "kedatangan rombongan tidak sesuai dengan jadwal kedatangan kapal KPM (kongsi tiga) yang dicarter, sehingga jamaah harus menunggu dan tinggal di alam terbuka tanpa fasilitas yang memadai, memang benar kapal lain telah tersedia tetapi karena telah sekaligus 
membayar tiket pulang, dan tiket tidak dapat dikembalikan maka terpaksa menunggu kapal yang dicarter."11 Bahkan yang lebih mengerikannya lagi, diantara mereka yang kurang beruntung ada yang akhirnya dijadikan budak, "calon jamaah terlantar di Singapura, meskipun dalam rencananya hendak diberangkatkan ke Numea (pulau kecil jajahan Prancis di Samudera Pasifik) untuk dijadikan budak."12 Para jamaah terjebak dalam satu-satunya pilihan untuk keberangkatan dari tanah air yakni Firma Herklots, sedangkan pilihan lain adalah Firma AlSegaff yang kedudukannya berada di Singapura. Jamaah yang hendak menggunakan jasa Firma Al-segaff terlebih dahulu harus berangkat ke Singapura dengan berlayar menggunakan perahu lokal menyeberangi selat Malaka. Disamping memiliki jasa layanan haji, ternyata Firma Al-Segaff juga bergerak dalam bidang perkebunan karet di Johor dan Malaysia.Situasi politik dunia pada saat itu adalah baru diberlakukannya politik "pintu terbuka' dengan kata lainpara investor bebas menanamkan modalnya dimana-mana. Hal ini mengakibatkan tumbuh suburnya pembukaan lahan-lahan perkebunan karet dan dibutuhkannya tenaga kerja sebanyak-banyaknya.

Firma Al-Segaff hadir untuk menjawab tantangan pasar global yang begitu menjanjikan dengan caranya yang unik, yakni memanfaatkan jamaah haji yang kehabisan uanguntuk pulang setelah ia rampok dengan pungutan-pungutan tak jelas seperti halnya Firma Harklots. Para syekh atau orang yang membantu di lapangan dalam prosesi badah haji kerap mengeruk keuntungan dari para jamaah, bahkan tak segan-segan melakukan penipuan. Firma Al-segaff benar-benar kapitalis sejati yang menghisap tanpa ampun dan belas kesihan, "Al-segaff melihat peluang untuk merekrut tenaga buruh perkebunan dengan memanfaatkan jamaah haji Jawa yang telah selesai menunaikan ibadah haji dan kehabisan uang untuk pulang ke tanah air. Kepada mereka ditawarkan sejumlah uang dalam bentuk pinjaman untuk membeli tiket kapal kembali ke tanah air. Apabila mereka setuju maka akan dibuatkan kontrak kerja dan langsung di bawa dari Makah ke Malaka."13

Melihat fenomena haji yang sarat dengan penipuan dan permainan kapitalis, kiranya tingkat keberangkatan haji akan menurun, namun pada kenyataannya terus meningkat seperti semua hal mengerikan yang dilakukan oleh Firma Herklots dan Al-segaff hanyalah cobaan sebelum sampai ke tanah suci, dan gelar haji terlalu menggiurkan untuk dilepaskan. Dan ternyata ada fenomena lain dikalangan masyarakat pada waktu itu yang cukup mengherankan sekaligus menggelikan, “jamaah yang tidak meneruskan perjalanan ke Makah karena kehabisan uang hanya sampai di Singapura saja, lalu kembali ke kampung halaman masingmasing. Ada istilah khusus bagi mereka yang hanya sampai Singapura yakni dengan menyandang gelar haji Singapura. Hal ini terjadi karena prilaku jamaah yang dengan berani menyandang gelar haji dan memakai kopiah serta baju haji."14 Kasus ini adalah salah satu contoh kesadaran palsu yang telah merasuki pola pikir masyarakat.Dimana gelar haji begitu penting, bahkan jauh lebih penting dari 
pada ritual haji itu sendiri dan niatannya untuk menunaikan rukun Islam kelima.

Tingginya keinginan masyrakat unuk menunaikan ibadah haji ternyata bukan hanya karenahal-hal seperti yang di isyarakatkan dalam ajaran agama Islam, namun juga dipengaruhi oleh faktor lain. Seperti dalam sebuah suratSnouck Hurgronje kepada Gubernur Jenderal Hindia Belanda atas laporannya dalam beberapa kali penyamaran yang ia lakoni sebagai jamaah haji ditengah-tengah masyarakat muslim Nusantara, “dikatakan bahwa ada beberapa hal yang menggiurkan masyarakat sehingga begitu berlomba-lomba dalam menunaikan ibadah haji; 1). Bertambahnya kehormatan yang akan dinikmati sesudah kembali ke tanah air. 2). Adanya keyakinan bahwa perjalanan haji merupakan peralihan yang bergengsi meunuju kehidupan baru dalam keimanan. 3. Atau justru beranggapan perjalanan tersebut sebagai tamasya ke tanah suci. 4). Bahkan banyak orang yang masih naik haji juga pada usia lanjut dengan keinginan untuk meninggal di tanah suci dan di kubur disana."15 Terlihat jelas bahwa haji telah menjadi sebuah kelas sosial tersendiri dalam masyarakat Nusantara di masa kolonial. Seorang masyarakat biasa berkeyakinan apabila kemudian telah menyandang gelar haji, maka akan secara otomatis naik pada kelas yang lebih tinggi dalam tatanan masyarakat. Kelas haji menjadi kelas yang dihormati, disanjung dan ditinggikan. Tanpa disadari kelas haji berubah menjadi sebuah kelas sosial dalam struktur kehidupan masyarakat dan perlahan mengalami peralihan dari sebuah ritual yang berlandaskan keimanan kepada sesuatu hal yang bersifat keduniawian.

\section{b. Haji Di Masa Kini}

Menjelang musim haji segenap televisi dan media masa lainnya seperti sibuk meberitakan kehebohanberhaji. Iklan dan browsur bertebaran dimanamana, begitu juga dengan obrolan para tetangga. Haji dimasa kini perlahan berubah menjadi gaya hidup (life style). Puluhan agen perjalanan haji bisa kita temukan disetiap kota di seluruh penjuru Indonesia. Ada ratusan website tentang haji dan segala pernak-perniknya yang bisa di akses setiap orang di dunia maya. Dari paket paling mewah dengan segala sarana istimewa, sampai paket paling murah dengan segala macam penipuannya. Saya pernah mengenal saudagar kaya yang begitu gemar naik haji dan umroh. Tidak ada yang salah atapun menyalahi aturan agama, namun apabila kita melihat secara psikologis masyarakat, kelas haji tampak seperti Perlombaanyang dipertontonkan demi pujian dan menaikkan strata sosial.

Melihat jumlah jamaah haji yang begitu luar biasa terkadang membuat kita heran, ternyata bangsa ini berpenduduk makmur dan masuk dalam tingkat kesejahteraan yang mapan.Mengutip dari berita kompasiana disebutkan bahwa, "sulitnya berangkat haji bukan karena tidak mampu melunasi tingginya biaya $\mathrm{ONH}$ (ongkos naik haji), namun disebabkan karena peraturan pemerintah yang mengharuskan setiap orang harus antri menunggu giliran keberangkatan ke tanah suci. Kata lain, kuota terbatas. Di Jawa Timur hingga berita itu dirilis, kuota (jatah) haji reguler untuk tahun 2017 sudah habis, jadi jika calon jamaah haji yang ingin berangkat menunaikan ibadah 
haji harus menunggu 7 sampai 8 tahun kedepan."16 Akibat kelangkaan tiket haji ini maka muncul trend baru dalam masyarakat yakni ibadah umroh.Umroh berasal dari kata amarayang berarti mendiami suatu tempat. Adapun waktu pelaksanaannya berbeda dengan ibdah haji, yakni bisa dilakukan kapan saja. Sehingga seoarang individu yang masuk dalam daftar antri untuk sementara waktu bisa melakukan umroh sembari menunggu keberangkatan naik haji. Terlihat ada kecendrungan atau mungkin pembentukan citra personal, atau malah telah menjadi gaya hidup trend masa kini.

Ongkos ibadah haji tahun 2011 sesuai dengan keputusan komisi VIII DPR sejumlah Rp 30.771.900, namun harga ini hanyalah untuk biaya haji reguler. Mengingat lamanya waktu antrian untuk bisa naik haji, muncul sebuah model paket haji baru yang diberi nama ONH Plus. "Masih bingung pilih haji regular atau haji ONH Plus? Pertama adalah lamanya antrian, haji regular dan dibeberapa daerah harus antri minimal 10 tahun, artinya bila kita daftar tahun 2012 maka baru bisa berangkat tahun 2022. Khusus antrian haji plus cukup tiga tahun saja" (www.cheriatravel.com). Ini adalah iklan yang saya kutip dari salah satu website yang bergerak dalam bidang layanan haji. Baik haji regular maupun haji plus samasama dikelola oleh DEPAG (Departemen Agama). Iklan yang cukup mengelitik. Bisa jadi menaruh curiga apakah sulitnya naik haji dengan antrian panjang 10 tahun adalah bentuk barudari taktik strategi penjualan kapitalis dalam menciptakan rekayasa kondisi seoalh-olah begitu sulit dan terbatasnya kesempatan berhaji, sejalan dengan hal ini, masyarakatpun akhirnya berkompetisi untuk membeli tiket, dan alhasil harga tiket pun bisa dimainkan para capital. Simpel saja kita ambil perbandingannya dengan contoh anak kecil yang rebutan boneka barby atau novel Harypotter dengan slogan "terbatas", alhasil pembelian membludak dan antrian di took buku Gramedia bisa mencapai 10 meter. Kita patut curiga, bahwa kapitalis dengan cara barunya ini mulai membentuk kembali kesadaran palsu yang mulai using untuk menciptkan rasa yang sangat ingin dan bahkan mengakibatkan kecanduan untuk naik haji. Bukan suatu hal yang aneh bila ada tetangga sebelah yang jual tanah jual celana demi ongkos naik haji yang masih harus ngantri 10 tahun, padahal itulah semua harta benda yang ia miliki untuk hidup dan makan sehari-hari.

Fenomena haji begitu luar biasa di dalam masyarakat Indonesia. Jumlahhaji dalam satu kelurahan bisa mencapai puluhan. Bila musim keberangkatan dan kedatangan haji tiba, dalam satu hari bisa kita jumpai 3 sampai 4 undangan acara syukuran kerumah haji baru ataupun haji yang sudah empat kali naik haji. Kita patut menyesalkan hal ini, dengan jumlah haji yang sedemikian banyak dalam masyarakat, tetapi kenapa kasus korupsi, pengangguran dan kemiskinanbegitu marak di negeri ini. Apakah haji telah bermetamorfosadalam sebuah bentuk baruyang sengaja diciptakan oleh kapitalis? Bentuk yang seperti apa dan kedepannya akan bagaimana, ini masih jadi tandatanya. Ataukah pada dasarnya kelas haji hanyalah kelas sosial yang sedari dulu sengaja dibentuk sedemikian rupa oleh haji-haji itu sendiri yang tidak ubahnya seperti raja-raja Jawa yang 
menciptakan gelarnya dengan mengagungkan keturunannya seperti mitos-mitos khayalan?

Namun pada kenyataannya, haji tetap menjadi sebuah gelar yang teramat penting guna meningkatkan status social dan sebuah pencitraan kesalehan.Sebuah pencitraan yang dibentuk atas kemunafikan demi legitimasi kesuciandimata masyarakat. Dan kini gelar haji harus dicantumkan dalam nama seseorang tidak ubahnya dengan gelar akademik. Haji dalam kesadaran masyarakat hanyalah sebuah kebanggaan semu yang dipakai sebagai topeng untuk menandakan keimanan dan kedudukan dalam masyarakatnya yang mayoritas muslim.

\section{c. Kelas Haji Kelas Sosial}

Salah satu ibadah yang wajib dilaksanakan setiap muslim yang mampu, baik secara fisik maupun finansial adalah ibadah haji. Setiap tahunnya jutaan orang dari berbagai penjuru dunia berbondongbondong menuju tanah suci. Panggilan haji bukan hanya mampu melintasi batasbatas negara dan politik, tapi juga batasbatas sosial ekonomi dan sosial budaya. Kerumunan jutaan manusia yang tiap tahunnya berbendong-bondong ke Makkah tidak ubahnya seperti tumpukan gula dimata para kapitalis yang menunggu untuk diperebutkan. Masyarakat merupakan bentukan kapitalis kuno dengan struktur sosial yang terlahir dari mode produksi. Dimana ada golongan yang sangat mengusai alat-alat produksi dibandingkan golongan lain sehingga memiliki wewenang untuk mengatur yang lainnya, "bahwa produksi dan konsumsi yang maksimal merupakan tujuan masyarakat yang tidak boleh dipetanyakan lagi."17 Manusia sebagai makhluk sosial yang tidak bisa hidup sendiri memerlukan bantuan orang lain untuk memenuhi kebutuhannya, yang pada era modern seperti sekarang peranannya telah digantikan oleh uang. Uang merupakan benda sosial yang paling sosial, sebab dengan uang anda akanditerima dan bisa memenuhi segala kebutuhan yang diperlukan, "marx memberikan contoh kebutuhan yang ditimbulkan oleh struktur masyarakat yang kapitalistik, yakni kebutuhan terhadap uang."18 Menyikapi hal tersebut, ibadah haji yang pada hakikatnya adalah sebuah ritual dan komunikasi dengan sang pencipta, posisinya telah dikendalikan dengan uang sebagai benda sosial. Contoh sederhananya adalah $\mathrm{ONH}$ regular dengan $\mathrm{ONH}$ plus, dengan mengeluarkan uang yang lebih banyak tidak perlu antri 10 tahun untuk naik haji.

"Bukanlah kesadaran manusia yang menentukan ke-ada-annya, tetapi sebaliknya, ke-ada-an sosialnyalah yang menentukan kesadarannya."19 Lingkungan telah menciptakan pola-pola pikir manusia didalamnya. Pembentukan pola-pola pikir dan ideologiini bisa disebut dengan penciptaan kesadaran palsu. Kapitalis menciptakan kesadarankesadaran palsu untuk membentuk kekuatan-kekuatan produksiyang menguntungkan para kapital. Penciptaan kesadaran ini dilangsungkan secara kasat mata dalamwaktu yang tidak disadari oleh masyarakat. Berhaji pada masa kolonial penuh dengan penghisapan kapital yang sangat merugikan jamaah, namun hal itu tidak menurunkan jumlah keberangkatan jamaah ke tanah suci, 
bahkan setiap tahunnya semakin meningkat. Hal ini dikarenakan politik yang dimainkan Kapitalis begitu pintar, yakni dengan menciptakan kesadaran palsu dalam bentuk peningkatan biaya $\mathrm{ONH}$ (ongkos naik haji) dan isu pan islamisme yang di cap berbahaya, sehingga melahirkan pandangan bahwa haji itu mahal (eksklusif) dan orang yang berhaji adalah orang yang mampu menahan cobaan dan menghadapi tantangan yang ada pasa saat itu (Resolusi 1825).

Lantas, terciptalah kelas haji sebagai sebuah kelas sosial baru dalam masyarakat. Pemerintah kolonial dengan strategi yang matang telah membantuk kelas haji dalam tatanan kehidupan masyarakat kolonial 'nusantara'. Pihak kolonial sebagai tuan kapitalis telah membentuk pola pikir masyarakat nusantara pada masa itu,bahwa setelah berhaji seseorang akan menjadi orang yang luar biasa, dan menjadi orang yang sangat dihargai dan dihormati dikalangan masyarakat serta diberikan hak istimewa setingkat lebih tinggi dibanding yang bukan haji. Kesadaran palsu tersebut kemudian menciptkan sebuah ruang kelas sosial, sehinggagelar haji mempunyai kedudukan tersendiri dalam tatanan masyarakat Indoneisa yang mayoritas muslim. Jelaslah bila kita simpulkan bahwa kapitalis dimasa kolonial sengaja menciptkan kesadaran palsu untuk meraup keuntungan sebesar-besarnya yang kemudian pada akhirnya hal tersebut menciptkan sebuah runag kelas sosial baru dalam masyarakat, yakni kelas haji.

Benang merah yang bisa kita tarik adalah bahwa kesadaran palsu dan pembentukan kelas sosial yang diciptakan pemerintah kolonial yang berperan sebagai kapitalis, hingga saat ini masih terus berlanjut. Kecendrungan masyarakat muslim Indonesia untuk selalu berhaji terus meningkat. Dimana kelas haji sebagai suatu kelas sosial dalam masyarakatyang kedudukannya belum luntur hingga sekarang. Kelas haji tetap menjadi kelas sosial yang dihargai dan dihormati, dan dimana pada zaman sekarang kelas social ini meningkat semakin diperebutkan dan diinginkan orang dibandingkan pada zaman kolonial. Dalam hal ini terdapat semacam peningkatan dan kesadaran, dimana keimanan "ke-alim-an" sangat dupengaruhikelas social 'haji' dalam masyarakat dan bahkan telah menjadi gaya hidup. Terdapat fenomena-fenomena yang sulit untuk dimengerti dan mungkin butuh suatu pengkajian khusus untuk hal ini, bahwa mengapa orang-orang pada masa sekarang begitu berlomba-lomba untuk terlihat alim atau terlihat beriman dimata orang lain dan lingkungannya (pencitraan kesalehan) dibandungkan pada masa lampau? Apakah kemunafikan individu yang begitu besar atau kesadaran palsu yang diciptakan para kapitalis telah berhasil dan sudah sangat akut? Jawaban nya butuh pendalaman lebih jauh dan dilihat dari sudut pandang yang lebih kritis dari sekedar kecurigaan terhadap kapitalisme.

\section{Kesimpulan}

Fenomena haji dimasa kini yang sarat penipuan dan antri hingga tujuh tahun adalah satu bentuk kesadaran palsu mode baru yang diciptkan kapitalis dalam masayrakat. Edisi terbatas memang selalu menggiurkan dan menghebohkan, dan itu 
sudah menjadi kodrat alamiahnya. Keterbatasan quota jamaah haji adalah model baru trik kapitalis dalam pembentukan kesadaran palsu, dimana haji akan semakinberkesan eksklusif, terbatas dan penuh perjuangan untuk mendapatkannya sehingga semua orang semakin berlomba-lomba memperebutkannya. Bahkan kasus penipuan terkait UMROH yang berulangulang kali tidak menimbulkan efek jera dan pembelajaran bagi masyarakat kita. Ditahun 2017 saja ada lebh dari 10 kasus penipuan haji, dengan modus yang mirip, yakni menwarkan paket lebih murah, keberangkatan yang lebih awal, fasilitas cukup mewah, lalu tiba-tiba batal dengan alasan visa, atau keselahan teknis yang tidak masuk akal.

Ini lah fenomena yang ada, dimana tuan-tuan kapitalisme telah membelokkan sebuah ibadah suci yang penuh kesakralan, keihklhasan, kesederhanaan, tanpa mengharap pujian 'semata-mata mengharapkan ridho Allah S.W.T, lalu berubah menjadi sebuah kelas sosial dalam masyarakat Indonesia hingga sekarang. Sebuah kelas baru telah tercipta, kelas bernama kelas haji,suatu kelas pencitraan keimanan yang kini begitu dicari sebagai topeng yang mampu menaikkan posisi seseorang dalam masyarakat, bahkan penting untuk kampeye politik pilkada 2018 yang tengah marak. Kapitalis nyata-nyatanya berhasil dalam strategi pemasarannya. Mmuncul pertanyaan baru, apakah selanjutnya para tuan kapitalis juga akan memperjual belikan dosa dan pahala, surga dan neraka sebagai mode produksi baru oleh para kapitalis dengan model dan strateginya yang kasat mata? Kelas haji, kelas sosial, bentukan kapitalisme, dimana kesadaran palsu sebagai satu rangkaian utuh dalam pembentukannya.

\section{Endnote}

${ }^{1}$ Turner, 2005.Hlm. 151.

2Turner, 2005.Hlm. 202.

${ }^{3}$ Majid, 2008. Hlm.2.

${ }^{4}$ (Majid, 2008.Hlm. 3).

${ }^{5}$ (Majid, 2008.Hlm. 5).

${ }^{6}$ (Majid, 2008.Hlm. 67).

${ }^{7}$ (Majid, 2008.Hlm. 71).

${ }^{8}$ (Majid, 2008. Hlm. 129).

${ }^{9}$ (Majid, 2008. Hlm. 138).

${ }^{10}$ (Majid, 2008. Hlm. 137).

${ }^{11}$ (Majid, 2008. Hlm. 138).

${ }^{12}$ (Majid, 2008.Hlm. 156).

${ }^{13}$ (Majid, 2008.Hlm. 159).

${ }^{14}$ (Majid, 2008.Hlm. 96).

${ }^{15}$ (Majid, 2008.Hlm. 104).

${ }^{16}$ (kompasiana, 3 Juni 2010).

${ }^{17}$ (Fromm, 2001. Hlm. 48).

${ }^{18}$ (Fromm, 2001. Hlm. 35).

${ }^{19}$ (Fromm, 2001. Hlm. 26).

\section{Daftar Pustaka}

Fromm, Eric. 2001. Konsep Manusia

Menurut Marx. Pustaka Pelajar.

Yogyakarta.

Geertz, Clifford. 1981. Abangan, Santri, Priyayi Dalam Masyarakat Jawa. Pustaka Jaya. Jakarta.

Majid, M. Dien. 2008. Berhaji di Masa Kolonial. CV Sejahtera. Jakarta.

Reid, Anthony. 2011. Asia Tenggara

Dalam Kurun Niaga 1450-1680. Yayasan

Pustaka Obor Indonesia. Jakarta. 2011.

Menuju Sejarah Sumatera: Antara Indonesia dan Dunia. KITLV. Jakarta. 
Turner, Jack. 2005. Sejarah Rempah:

Dari Erotisme Sampai ke Imprealisme.

Komunitas Bambu. Jakarta.

www.cheriatravel.com; di unduh tanggal 7 Januari 2012.

www.kompasiana.com/2010/06/03

Linformasi-quota-haji-2011/; di unduh tangal 7 Januari 2012. 